DOI 10.36622/VSTU.2021.50.2.003

UDC 536.491

N. J. Saprykina ${ }^{1}$

\title{
TECHNIQUE FOR DESIGNING ENGINEERING SYSTEMS WHEN OPERATING ON A LOW-POTENTIAL ENERGY SOURCE
}

\author{
Astrakhan State University of Architecture and Civil Engineering ${ }^{1}$ \\ Russia, Astrakhan
}

${ }^{1}$ Senior lecturer of the Dept. of Engineering Systems and Ecology, tel.: 8-927-661-48-60, e-mail: nadin_id@,mail.ru

Statement of the problem. To develop a design methodology for air conditioning and heat supply systems operating for a long period on the basis of a vertical geothermal well.

Results. A description and procedure of the proposed design methodology for calculating the main parameters of air conditioning and heat supply systems are given.

Conclusions. As a result of the study, a methodology for designing air conditioning and heat supply systems based on a low-potential energy source (NIE) was proposed. It allows you to calculate the required number of geothermal wells as accurately as possible, taking into account the technological features of the operation of engineering systems, which allows you to minimize the amount of capital and operational investments for the installation of heat pump equipment and its components.

Keywords: heat pump, design methodology, vertical geothermal well.

Introduction. Almost no information available on the operation of air conditioning and heat supply systems running on a low-potential energy source (ground mass) for a long time causes lack of data on the performance of the heat pump. There is a likelihood of unsustainable operation of engineering systems under such conditions, i,e.,, reduced productivity and deterioration of technical and economic indicators. Note that it is quite a challenge to track the dynamics of operation. In most cases, it is superficial, and it is almost impossible to evaluate the operation of systems in the long term.

Therefore the main objective of the research is to develop a methodology for calculating air conditioning and heating systems running on low-potential geothermal energy sources considering a long-term operation. The main objective of the study is to obtain the possibility of using the resulting methods in a range of climatic regions that were crucial the theory of similarity employed for designing the method.

(C) Saprykina N. J., 2021 
There have been some studies into the operation of heat pumps running on low-potential energy sources. They aimed to study and predict changes in temperature fields around the operated well and have been well documented in research papers $[2-8,11-12,14,18]$. Evaluation of the efficiency of the heat pump at during long-term operation in a few technological modes is reflected in $[9-10,17,21]$. The influence of groundwater on the temperature field is described in [1, 19-20].

\section{The major stages of designing air conditioning and heating systems running on low-}

potential energy source. Unlike classical design, such calculation systems call for a more nuanced approach.

The calculation method includes the following stages:

1) collection and analysis of source data;

2) preparation of the technical task;

3) formulation of pre-design solutions;

4) coordination of the accepted solutions with the customer;

5) approval of the adopted solutions;

6) design of engineering systems;

7) estimation.

Prior to starting the design, the source data is collected and analyzed. Then the terms of reference are estimated, including the functions of the designed engineering systems (heating, hot water supply, air conditioning) or the production objectives (technical heat supply, cold supply), as well as the number of employees or residents. Since there are plans to install vertical geothermal wells with a sufficient length of $75 \mathrm{~m}$ and more, it is appropriate to specify existing engineering networks underway in the design area. According to the data of the terms of reference, the engineer forms the basis for followup calculation.

On top of that, data on engineering and geological surveys is essential for identifying the thermal and physical characteristics of the soil, the rate of filtration of groundwater, etc.

2. Sequence of design techniques. In compliance with the climatic data of the design area, the following calculations are conducted: the heat balance of the heating system is calculated, the demand for hot water supply and heat inflows are calculated. Using the obtained data, the capacity of the heat pump equipment is selected.

As an example, let us look at the object of a residential building in Astrakhan with an area of $150 \mathrm{~m}^{2}$ which provides engineering systems (air conditioning, heating, hot water), the number of residents is 5 people. According to the original data, the calculation of the required heat loads is made, the schedule of annual active loads is designed (Fig. 1). 


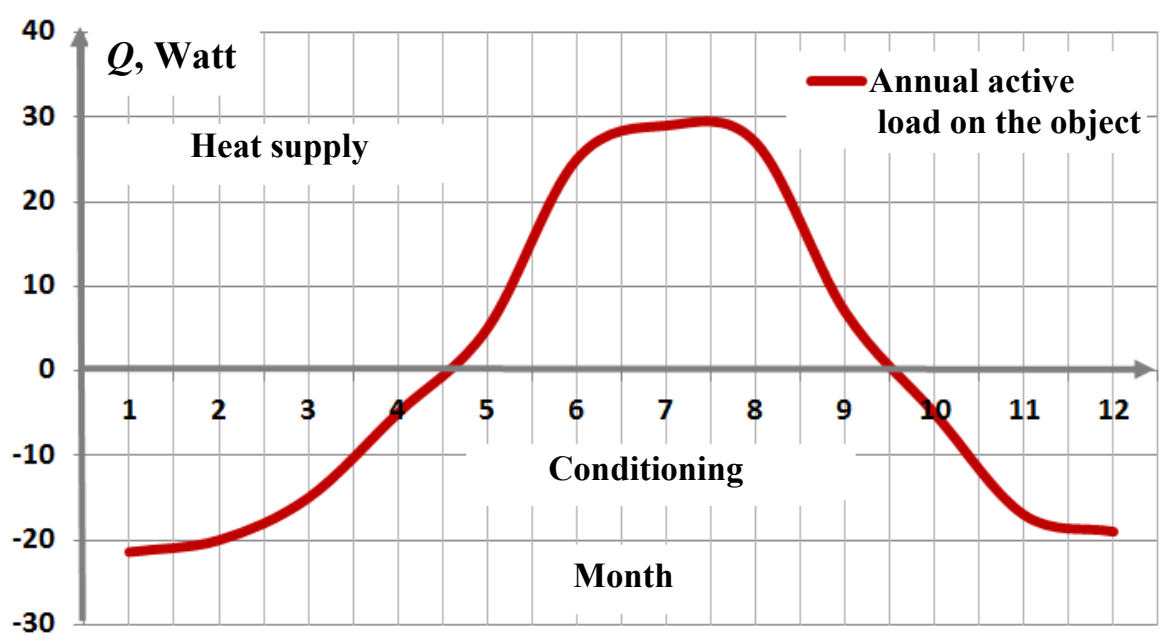

Fig. 1. Schedule of annual active loads on engineering systems for the designed apartment house

The curve of active loads (Fig. 1) can be substituted by discrete sections equal in area to the actual ones, as the projected objects are generally thought of as enlarged indicators (Fig. 2).

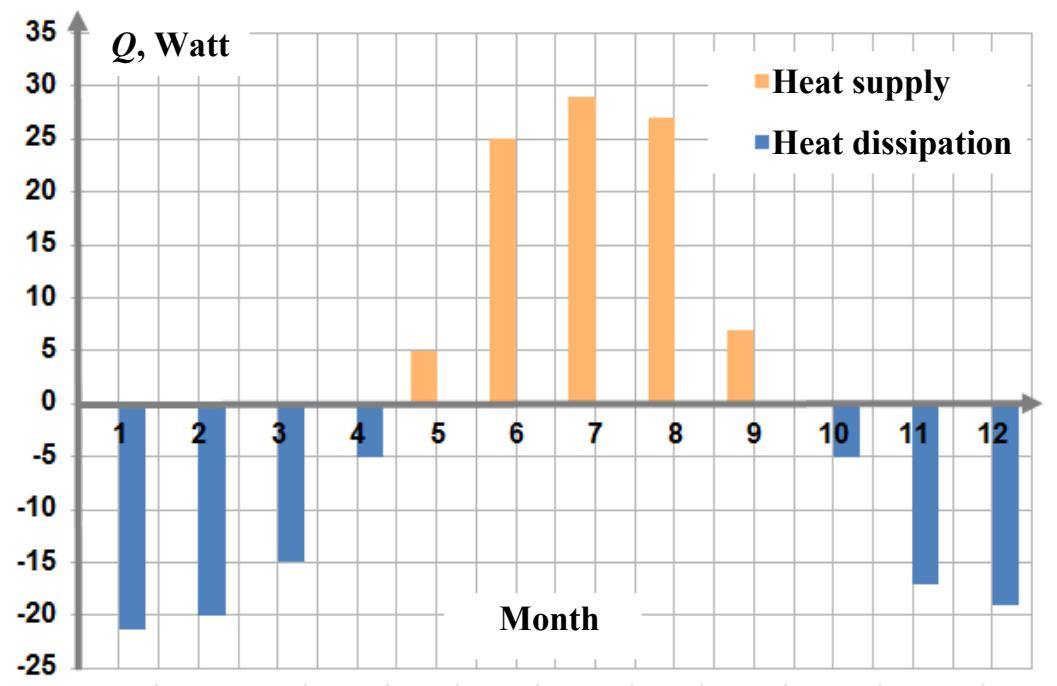

Fig. 2. Averaged annual load

In order to identify the amount of heat supplied to the vertical well in the summer season and dissipated during the heating period, a new quantitative characteristic was introduced, i.e., the regeneration coefficient [15]. It is given by formula (1) using the obtained active averaged loads:

$$
k_{p}=\frac{Q_{\text {supply }}}{Q_{\text {dissipation }}},
$$


where $Q_{\text {supply }}$ is the amount of flow in the warm period of the year, Watt $/ \mathrm{m}^{2} ; Q_{\text {dissipation }}$ is the amount of dissipated flow in the cold period of the year, Watt $/ \mathrm{m}^{2}$.

The efficiency of the heat pump depends on the temperature of the low-potential energy source. The criterion dependences [16] are set forth which allow one to calculate the predicted values of temperatures at the bottom of the well during the operation of the heat pump in different modes:

— only for heat supply:

$$
\Theta=-5 \cdot 10^{-9} \cdot Q \cdot F^{2}+2 \cdot 10^{-8} F o \cdot Q+0.0003 \cdot Q+5.1,
$$

where $F_{O}$ is the Fourier test, $\Theta$ is the dimensionless temperature, $Q$ is a relative thermal flow;

- with seasonal changes from heat supply to air conditioning and the other way around:

$$
\Theta=-5 \cdot 10^{-9} \cdot Q \cdot F o^{2}+2 \cdot 10^{-8} F o \cdot Q+0.0003 \cdot Q+5.1\left(0.0004 \cdot k_{p}+0.947\right),
$$

where $F_{O}$ is the Fourier test, $\Theta$ is the dimensionless temperature, $Q$ is a relative thermal flow, $k_{p}$ is the regeneration coefficient;

— considering the effect of the groundwater:

$$
\begin{aligned}
& \Theta=\left(-5 \cdot 10^{-9} \cdot Q \cdot F O^{2}+2 \cdot 10^{-8} F o \cdot Q+0.0003 \cdot Q+\right. \\
& \left.+5.1 \cdot\left(0.0004 \cdot k_{p}+0.947\right)\right) \cdot(-0.0005 \cdot C+0.79)
\end{aligned}
$$

where $F_{O}$ is the Fourier test, $\Theta$ is the dimensionless temperature, $Q$ s a relative thermal flow, $k_{p}$ the regeneration coefficient, $C$ is the water exchange criterion.

In order to convert the obtained dimensionless temperature into the actual one, equation (5) is used:

$$
t_{\text {well }}=\left(\left(t_{\text {background }}-t_{\text {av.oc }}\right) \cdot \Theta\right)+t_{\text {av.oc }},
$$

where $t$ of the well is the temperature of the wall of the well at the moment of the finish of the operated period in question, ${ }^{\circ} \mathrm{C} ; t_{c p . o c}$ is the average annual climatic temperature of the environment, ${ }^{\circ} \mathrm{C}$; $t_{\text {background }}$ is the background temperature of the soil, ${ }^{\circ} \mathrm{C} ; \Theta$ is the dimensionless temperature.

The next stage of the design methodology includes calculating the design features of wells [15-16] and their number.

For this, let us calculate the total length of the well (6):

$$
L=Q o / q,
$$

where $Q o$ is the load on the heat supply system (or air conditioning) based on the heat balance calculations, Watt; $q$ is the amount of heat removed from the surface layer of the soil, $\mathrm{Watt} / \mathrm{m}^{2}$ 
The number of wells should be calculated in the following way (7):

$$
n_{\text {well }}^{\text {design }}=\frac{L}{l_{\text {specific }}}
$$

where $L$ is the design length of the well, $\mathrm{m}$; $l_{\text {specific }}$ is the specific length of the well adopted by assemblying organizations, $\mathrm{m}$ (in the range of $75-150$ ).

Then the number of wells is adjusted considering the regeneration coefficient (8):

$$
n_{\text {wells }}=n_{\text {wells }}^{\text {design }} \cdot k_{p},
$$

where $n_{\text {well }}^{\text {design }}$ is the deisgn number of wells; $k_{p}$ is the regeneration coefficient.

The capacity of the heat pump unit is defined by means of the conversion factor. It depends on the temperature difference between the RES and the consumer, as well as on the operating conditions. As the temperature of a low-potential energy source changes, so does the transformation coefficient. Fig. 3 shows a graph of the dependence of the change of the conversion factor on time and operation mode.

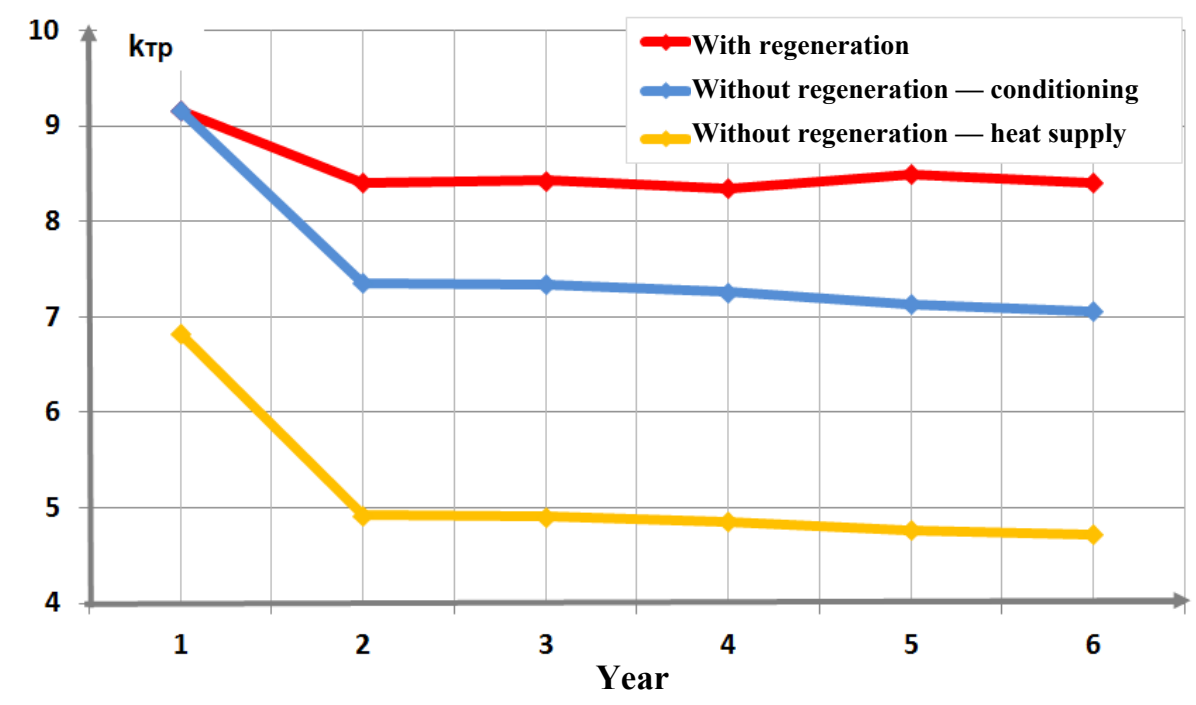

Fig. 3. Graph of the dependence of the change of the conversion factor on the time and operation mode

Due to the changes of thermal processes during the operation of the heat pump and the operation of the RES, there is a regeneration of the soil mass. Let us note the positive effect of the regeneration effect itself and the regeneration coefficient on the low-potential energy source (Fig. 3).

The next stage of the design methodology includes calculating technical and economic indicators and economic efficiency. Fig. 4 shows a graph of the dependence of the consumed thermal energy $(Q)$ on the conversion factor $(k t r)$ for different numbers of wells. 


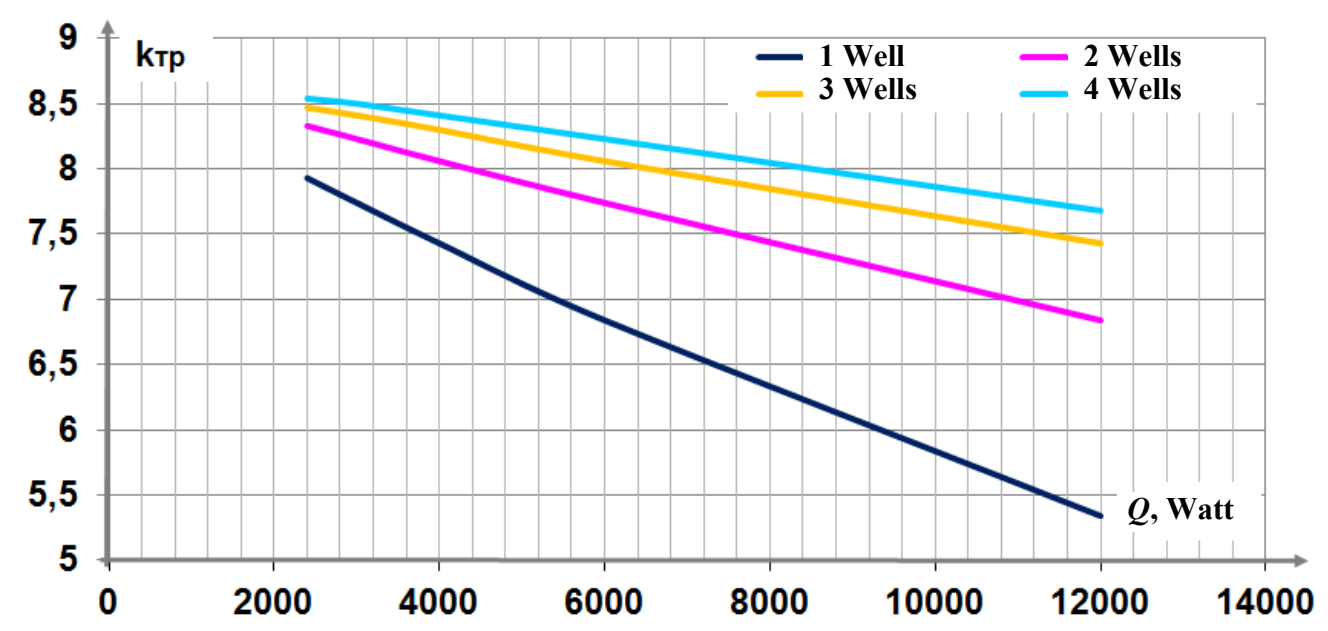

Fig. 4. Dependence of the conversion factor on the thermal load

The above technique can be represented as a block diagram (Fig. 5).

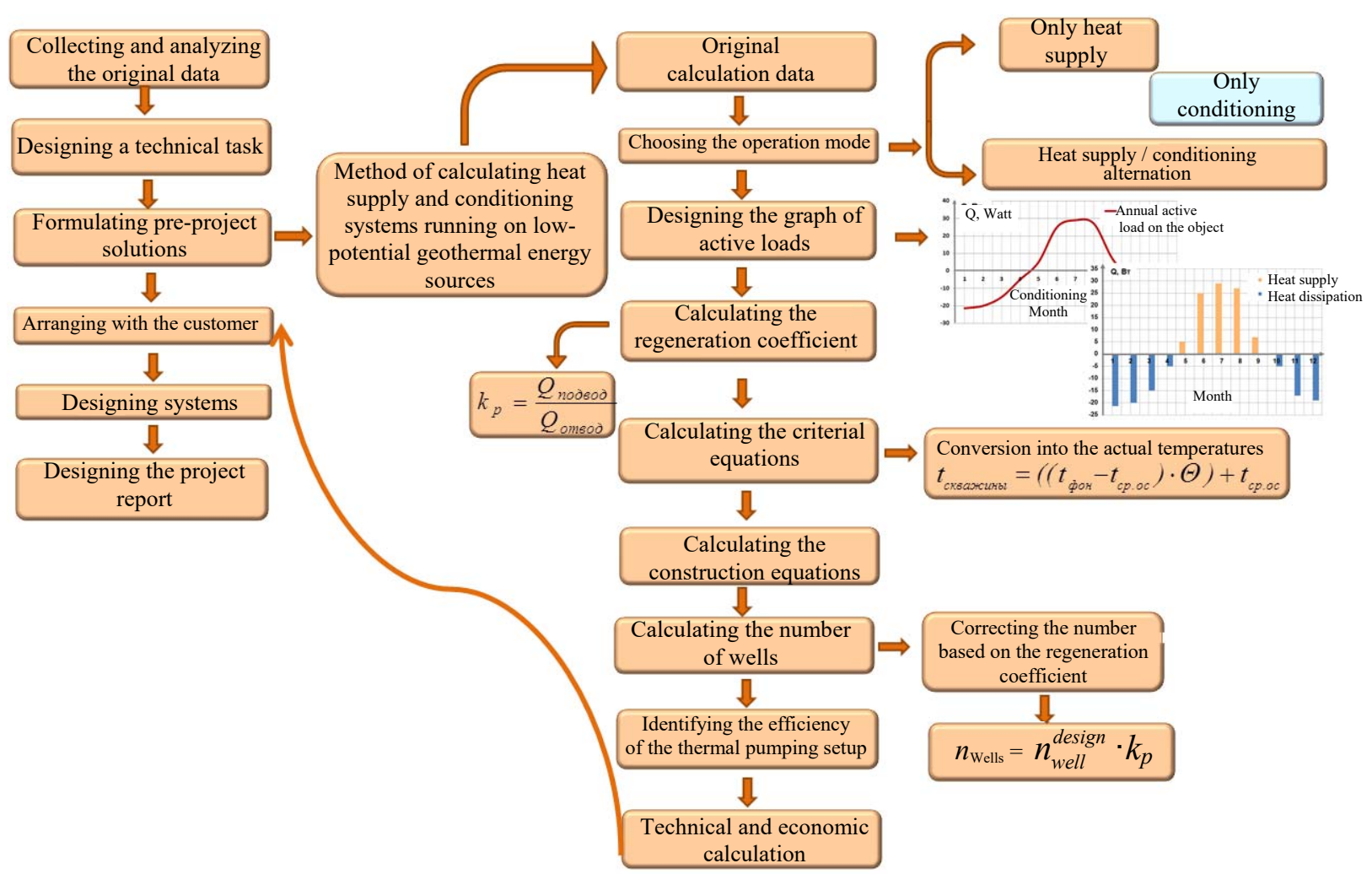

Fig. 5. Method of designing heat supply and conditioning systems using the RES

Conclusions. Based on the research findings, a technique is set forth that forms a sequence of calculation and design of heating and air conditioning systems running on low-potential geothermal energy sources. It involves predicting the change in the temperature field during long- 
term operation of a low-potential energy source at the stage of design and preparation of design estimates. This technique enables effective calculation of the optimal number of geothermal wells, the necessary heat pumping equipment and reduction in the time of preparation of design documentation by minimizing the amount of capital and operating costs.

\section{References}

1. Vasil'ev G. P. Geotermal'nye teplonasosnye sistemy teplosnabzheniya i effektivnost' ikh primeneniya v klimaticheskikh usloviyakh Rossii [Geothermal heat pump systems of heat supply and efficiency of their application in climatic conditions of Russia]. AVOK. Teplosnabzhenie, 2007, no. 5. Available at: http://www.abok.ru/for_spec/articles.php?nid=3685.

2. Vasil'ev G. P. Teplokhladosnabzhenie zdanii i sooruzhenii s ispol'zovaniem nizkopotentsial'noi teplovoi energii poverkhnostnykh sloev zemli. Diss. d-ra tekh. nauk [Heat and cold supply of buildings and structures using low-potential thermal energy of the surface layers of the earth. Dr. eng. sci. diss.]. Moscow, 2006. P. 423.

3. Glasko A. V., Fedotov A. A., Sidinyaev N. I., Khrapov P. V., Mel'nikova Yu. S. Modelirovanie dinamiki temperaturnogo polya osnovaniya zdaniya $\mathrm{v}$ kriolitozone [Modeling of the dynamics of the temperature field of the building base in the cryolithozone]. Elektronnoe nauchno-tekhnicheskoe izdanie MGTU im. N. E. Baumana «Nauka i obrazovanie», 2011, no. 12. Available at: http://www.technomag.edu.ru/doc/274059.html.

4. Ibragimov E. V., Kronik Ya. A., Pustovoit G. P. Opyt ispol'zovaniya teplovykh nasosov v kachestve sistem termostabilizatsii grunta $\mathrm{v}$ kriolitozone [Experience of using heat pumps as systems for thermal stabilization of soil in the cryolithozone]. OFMG, 2015, no. 5, pp. 23-26.

5. Kozlov S. S., Kozlov E. S. Zavisimost' temperaturnogo polya grunta ot teploty, teryaemoi ograzhdayushchei konstruktsiei podzemnykh sooruzhenii [Dependence of the ground temperature field on the heat lost by the enclosing structure of underground structures]. Sovremennye naukoemkie tekhnologii, 2013, no. 8, pp. 302-304.

6. Poddubnyi G. V. Temperaturnoe pole v grunte pod izolyatsiei bespodval'nogo kholodil'nika [Temperature field in the ground under the insulation of the basement refrigerator]. Izv. vuzov. Matematika, 1962, no. 6, pp. $101-107$.

7. Saprykina N. Yu. Povyshenie effektivnosti raboty sistem teplosnabzheniya i konditsionirovaniya, rabotayushchikh $\mathrm{v}$ komplekse $\mathrm{s}$ teplovym nasosom [Improving the efficiency of heat supply and air conditioning systems operating in combination with a heat pump]. Inzhenerno-stroitel'nyi vestnik Prikaspiya : nauchnotekhnicheskii zhurnal, 2018, no. 2 (24), pp. 17-23.

8. Saprykina N. Yu., Panov M. Ya. Issledovanie vliyaniya rezhimov raboty geotermal'noi skvazhiny s sistemami teplosnabzheniya i konditsionirovaniya v komplekse s teplovym nasosom na temperaturu gruntovogo plasta [Investigation of the influence of the operating modes of a geothermal well with heat supply and air conditioning systems in combination with a heat pump on the temperature of the ground layer]. Nauchnyi zhurnal stroitel'stva i arkhitektury, 2018, no. 4 (52), pp. 105-116.

9. Tarasova V. A., Kharlampidi D. Kh., Sherstyuk A. V. Modelirovanie teplovykh rezhimov sovmestnoi raboty gruntovogo teploobmennika i teplonasosnoi ustanovki [Simulation of thermal modes of joint operation of 
a ground heat exchanger and a heat pump unit]. Vostochno-Evropeiskii zhurnal peredovykh tekhnologii, 2011, no. $5 / 8(53)$, pp. $34-40$.

10. Trushevskii S. N., Strebkov D. S. Vechnaya merzlota, osnovaniya i teplovye nasosy [Permafrost, bases and heat pumps]. Vestnik VIESKh, 2014, no. 4 (14), pp. 11-15.

11. Fedyanin, V. Ya., Karpov M. K. Ispol'zovanie gruntovykh teploobmennikov v sistemakh teplosnabzheniya [Use of ground heat exchangers in heat supply systems]. Polzunovskii vestnik, 2006, no. 4, pp. 98 -103.

12. Fedyanin, V. Ya., Mikheev D. Ya. [Method of calculation of heat flows in a ground heat exchanger]. Materialy 61-i nauchno-tekhnicheskoi konferentsiya studentov, aspirantov i professorsko-prepodavatel'skogo sostava. Chast' 11. Energeticheskii fakul'tet [Materials of the 61st Scientific and Technical Conference of students, postgraduates and faculty. Part 11. Power Engineering Faculty]. Barnaul, Izd-vo AltGTU, 2003, pp. $12-14$.

13. Shishkin N. D., Prosvirina I. S. Otsenka effektivnosti primeneniya teplonasosnykh ustanovok v sistemakh teplosnabzheniya Astrakhanskoi oblasti [Evaluation of the efficiency of heat pump installations in the heat supply systems of the Astrakhan region]. Izvestiya AZhKKh, 2000, no. 4, p. 7.

14. Diao N., Li Q., Fang Z. Heat transfer in ground heat exchangers with groundwater advection. Int. J. Therm. Sci., 2004, vol. 43, pp. 1203-1211.

15. Hellström G., Sanner B., Klugescheid M., Gonka T., Mårtensoon S. Experience with the borehole heat exchanger software EED. Proc. MEGASTOCK. Sapporo, 1997, pp. 247-252.

16. Hepbasli A., Key A. Review on exergetic analysis and assessment of renewable energy resources for a sustainable future. Renewable and Sustainable Energy Reviews, 2008, no. 12, pp. 593 -661.

17. Monzó P., Acuña J., Mogensen P., Palm B. A study of the thermal response of a borehole field in winter and summer. International conference on applied energy ICAE, 2013, july, pp. $1-4$.

18. Nordell B., Söderlund M. Solar energy and heat storage. Luleå University of Technology, 2000.

19. Ozgener O., Hepbasli A. Modelling and performance evaluation of ground source (geothermal) heat pump systems. Energy and Buildings, 2007, no. 39, pp. 66-75.

20. Papatheodorou N. G., Fragogiannis G. I., Stamataki S. K. Transient simulation of a hybrid ground sourse heat pump system. 3rd International Conference «From Scientific Computing to Computational Engineering» 3 rd IC-SCCE Athens, 2008, july, pp. 9-12.

21. Seyboth K., Beurskens L., Langniss O., Sims R.E.H. Recognising the potential for renewable energy heating and cooling. Energy Policy, 2008, no. 36, pp. 2460-2463. 